Article

\title{
Hydrogeochemical Characteristics and the Suitability of Groundwater in the Alluvial-Diluvial Plain of Southwest Shandong Province, China
}

\author{
Zongjun Gao ${ }^{1}$, Jiutan Liu ${ }^{1}$, Jianguo Feng ${ }^{1, *}$, Min Wang ${ }^{1, *}$ and Guangwei $\mathrm{Wu}^{2}$ \\ 1 College of Earth Science and Engineering, Shandong University of Science and Technology, \\ Qingdao 266590, China \\ 2 Shandong Geological Environmental Monitoring Station, Jinan 250014, China \\ * Correspondence: fengjianguo20316@sohu.com (J.F.); brightwangm@163.com (M.W.)
}

Received: 15 July 2019; Accepted: 27 July 2019; Published: 30 July 2019

\begin{abstract}
The alluvial-diluvial plain of southwest Shandong Province is an important agricultural economic zone and energy base in Shandong Province. Groundwater plays an extremely significant role in the development of the regional social economy. In this study, 50 sets of water samples, collected from 25 wells during October 2016 and June 2017, were utilized to determine the hydrogeochemistry and the suitability of groundwater in the alluvial-diluvial plain of southwest Shandong Province for different applications, such as drinking and irrigation. Most of the water samples could be classified as hard-fresh water or hard-brackish water, and the dominant water types were $\mathrm{HCO}_{3}-\mathrm{Na}$ and mixed types. Water-rock interactions and evaporation were the dominant controlling factors in the formation of the hydrochemical components in the groundwater. Dissolutions of silicate, calcite, dolomite, and gypsum are the major reactions contributing and defining the groundwater chemistry in this plain. Moreover, cation exchange is a non-negligible hydrogeochemical process in this plain. Calculated saturation index (SI) values indicate that aragonite, calcite and dolomite are saturated, while the SI values for gypsum and halite are unsaturated. Based on fuzzy comprehensive evaluation, the groundwater quality ranges from excellent to very poor. More than $50 \%$ of all groundwater samples from 2016 are categorized as poor or very poor, suggesting that the water from these wells is not suitable for drinking. According to the sodium adsorption ratio and percentage sodium, most of the samples are suitable for agricultural irrigation. Overall, the quality of the groundwater in 2017 was found to be better than in 2016 .
\end{abstract}

Keywords: groundwater; hydrogeochemical characteristics; water quality assessment; alluvial-diluvial plain of southwest Shandong Province

\section{Introduction}

Groundwater is a significant strategic resource used to support social and economic development $[1,2]$. Groundwater resources and water quality are restrictive factors for development in many areas of the world [1,2]. In recent years, sustained population growth has caused continuous societal development and the excessive exploitation of groundwater resources [3]. The groundwater environment around the world has been affected and polluted to varying degrees [3]. Municipal sewage and wastewater discharged by industrial and mining enterprises infiltrate into the groundwater system and poses a serious threat to the quality of groundwater $[2,4,5]$. The analysis of groundwater chemistry and the evaluation of groundwater quality can reveal potential factors which control the chemical composition of groundwater and understand the sources of groundwater pollution [6]. These factors can lead to profound steps toward the protection and sustainable utilization of groundwater resources [6]. 
Therefore, in order to ensure access to clean water for the growing population, one needs to protect and utilize water resources carefully and sensibly. To achieve this goal, it is necessary to understand the origins and hydrochemistry of water. These two, seemingly simple aspects are at the center of many worldwide principal, social, and environmental programs $[7,8]$.

Evaluation of the hydrogeochemical characteristics and the suitability of groundwater for different uses has been extensively researched around the world [7-12]. These studies indicate that the hydrochemical composition and water quality of groundwater are influenced by natural factors (such as water-rock interactions, climate change, geological conditions, etc.) and anthropogenic activities such as industrial, agricultural, and domestic sewage discharge [7-12]. However, anthropogenic sources have become a dominant factor affecting the groundwater environment $[13,14]$. In previous studies, hydrochemical methods, such as Gibbs diagrams, Piper trilinear graphs, saturation index (SI), and ion ratio graphs, have commonly been used to determine which hydrogeochemical processes are occurring and the controlling factors in these processes [15-18]. Fuzzy comprehensive evaluation (FCE), sodium adsorption ratio (SAR), and percentage sodium (\% $\mathrm{Na}$ ) are popular methods used to determine the quality of groundwater and evaluating it for drinking and/or irrigation uses $[19,20]$.

The alluvial-diluvial plain in southwestern Shandong Province is an important agricultural economic zone and energy base in Shandong Province. The city of Heze in Shandong Province is a resource-water quality-engineering pattern water shortage city. In 2014, water resources in Heze per capita were only $167 \mathrm{~m}^{3}$, which was $8 \%$ of the national per capita value, and $54 \%$ of other cities in Shandong Province [21]. Groundwater is not only a crucial source of drinking water, but also an important source for agricultural irrigation and industrial water. However, research on groundwater hydrochemistry and water quality was relatively limited. In order to provide some basis for the rational development, scientific management, and protection of groundwater resources, the objectives of this study focus on two aspects: (1) investigating the hydrogeochemical characteristics and dominant water-rock processes of groundwater and (2) the evaluation of the quality of groundwater and its suitability for domestic and/or irrigation uses. These studies provide useful information for the rational development and protection of groundwater resources in the region, and also provide impetus for sustained and rapid development of the social economy.

\section{Study Area}

Shandong is one of the most developed provinces in China. The study area is situated in the southwest of Shandong Province and lies between the latitudes $114^{\circ} 48^{\prime} \mathrm{N}$ to $116^{\circ} 24^{\prime} \mathrm{N}$ and longitudes $34^{\circ} 52^{\prime} \mathrm{E}$ to $35^{\circ} 52^{\prime} \mathrm{E}$ (Figure 1). The study area has a warm, temperate, semi-humid monsoon continental climate, with distinct seasons and abundant sunshine. Annual average precipitation is $672.78 \mathrm{~mm}(1951-2012)$ and the annual average temperature is $13.6^{\circ} \mathrm{C}$. The precipitation varies greatly between years, with the alternation of high flow years and low flow years. Due to the geographical location, atmospheric circulation, and other factors, the regional distribution of precipitation is uneven. The amount of precipitation is generally greater in the south than in the north, and greater in the east than in the west. Heze City is situated in the Huaihe River basin, which belongs to the alluvial-diluvial plain of the Yellow River. All rivers collect and discharge to the Beijing-Hangzhou Canal and Nansi Lake. The principal rivers are Zhuzhaoxin River, Wanfu River and Dongyu River. The terrain of the study area gradually decreased in elevation from the southwest to the northeast. Except for a few low hills in the southeastern part of Juye County, the rest of the study area is located in the Yellow River flood plain with undulating topography.

The alluvial-diluvial plain in southwestern Shandong Province is covered by Quaternary and Neogene strata. According to the existing revealed stratigraphic data, the old to new strata are Paleozoic Ordovician, Carboniferous and Permian, Cenozoic Paleogene, Neogene and Quaternary (Table 1). Aquifer formations can be classified into the following five types from top to bottom: (1) Pore water-bearing rock group of loose rock type (shallow fresh water). It is mainly composed of the Quaternary alluvium of the Yellow River. The lithology is silt, silty clay, clay, and silty sand, with some 
medium and fine sand. The depth of the aquifer floor is generally around $20-40 \mathrm{~m}$. Affected by the alluvial diversion of the Yellow River, the distribution of sand is multi-layered, and the layers are separated by clay and silt, so the lower aquifer has micro-pressure bearing properties. The discontinuity of the horizontal distribution of each clay layer connects the upper and lower aquifers in different degrees. The movement characteristics and dynamic changes of groundwater are fairly consistent with the upper phreatic water, which can be regarded as a unified aquifer formation. Shallow groundwater is mainly infiltrated by atmospheric precipitation, accounting for $85 \%$ of the total water recharging the aquifers. In addition, river side seepage and farmland irrigation leakage are also important sources of water to recharge the aquifers. Shallow groundwater runoff conditions are affected by topography, geomorphology, and recharge sources. The area is the alluvial plain in the lower reaches of the Yellow River with flat terrain and the total flow of shallow groundwater from west to east. There are two main discharge modes of shallow groundwater: evaporation and exploitation. Shallow groundwater is one of the main sources of water for industrial, agricultural production, and living in the region, among which agricultural exploitation is the largest. (2) Middle porous aquifer rock group of loose rock type (medium salt water). These aquifers are situated under the shallow porous aquifer, with a floor depth of approximately $270 \mathrm{~m}$. The lithology is silty clay, clay, medium-fine sand, silty sand, and partly contains medium-coarse sand. (3) Deep porous aquifer rock group of loose rock type (deep fresh water). These aquifers are located under the middle porous aquifer and the depth of the floor is greater than $500 \mathrm{~m}$. The lithology is clay, silty clay, silt, and fine sand. The local distribution is medium-coarse sand with a thickness of 20-30 m. (4) Fractured aquifer formation of clastic rocks with carbonate rocks. These fractured aquifers are concealed under the loose beds of Quaternary and Neogene strata, with a roof depth of about $1000 \mathrm{~m}$, and consists mainly of Permian and Carboniferous sandstone, mudstones with limestone, and coal seams. (5) Fractured karst aquifer group of carbonate rocks. These fractured aquifers are buried under loose rock strata or coal measures strata and the lithology is mainly Ordovician limestone and dolomitic limestone.

Table 1. Summary table of stratigraphic division.

\begin{tabular}{|c|c|c|c|c|c|}
\hline \multicolumn{2}{|c|}{ Chronostratigraphic Unit } & \multicolumn{2}{|c|}{ Lithostratigraphic Unit } & \multirow{2}{*}{ Code } & \multirow{2}{*}{$\begin{array}{l}\text { Thickness } \\
\text { (m) }\end{array}$} \\
\hline Erathem & System & Group & Formation & & \\
\hline \multirow{5}{*}{ Cenozoic } & \multirow{2}{*}{ Quaternary } & & Huanghe Formation & $\mathrm{QHh}$ & $15-30$ \\
\hline & & & Pingyuan Formation & $\mathrm{QP}$ & $160-210$ \\
\hline & \multirow{2}{*}{ Neogene } & \multirow{2}{*}{$\begin{array}{l}\text { Huanghua } \\
\text { Group }\end{array}$} & Minghuazhen Formation & $\mathrm{NhM}$ & $500-700$ \\
\hline & & & Guantao Formation & NhG & $170-200$ \\
\hline & Paleogene & $\begin{array}{c}\text { Guanzhuang } \\
\text { Group }\end{array}$ & Dawenkou Formation & $\mathrm{EgD}$ & $0-260$ \\
\hline \multirow{5}{*}{ Palaeozoic } & \multirow{2}{*}{ Permian } & & Shihezi Formation & PŜ & $0-200$ \\
\hline & & \multirow{3}{*}{$\begin{array}{l}\text { Yuemeigou } \\
\text { Group }\end{array}$} & Shanxi Formation & PyS & $0-160$ \\
\hline & \multirow{2}{*}{ Carboniferous } & & Taiyuan Formation & C-PyT & $0-180$ \\
\hline & & & Bnexi Formation & CyB & $0-20$ \\
\hline & Ordovician & & Majiagou Formation & $\mathrm{OM}$ & 800 \\
\hline
\end{tabular}




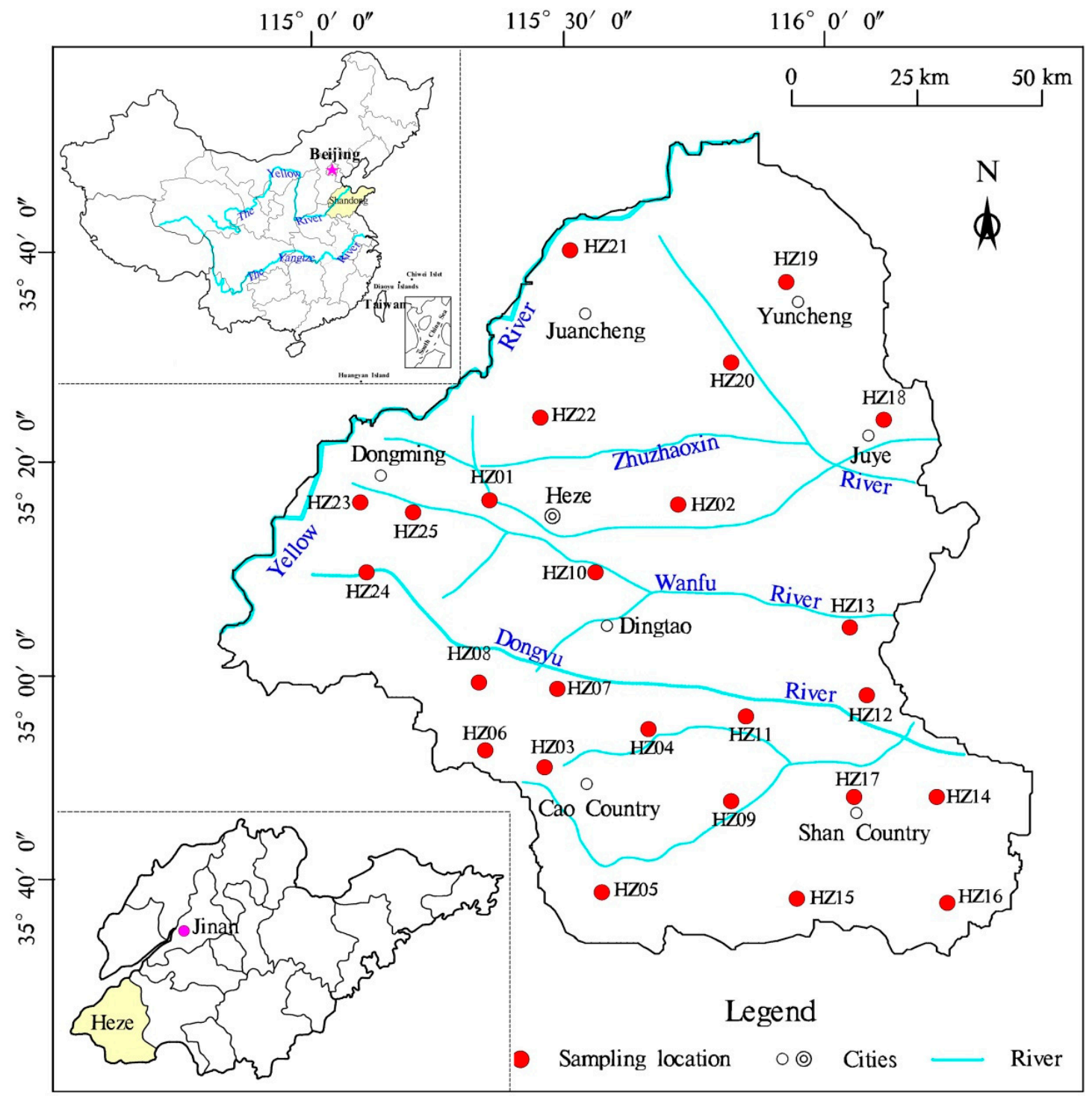

Figure 1. Location of the sampling sites and the study area.

\section{Materials and Methods}

\subsection{Sampling and Analysis}

In this study, a total of 50 water samples were collected from wells during October 2016 and June 2017. The depth of most sampling wells was less than $30 \mathrm{~m}$. In addition, the sampling locations in 2017 were the same as in 2016. Dry and clean polyethylene plastic bottles were used for sampling. Before collecting, all sampling bottles were cleaned 3-5 times with sample water. After sampling, all sample bottles were filled up with sample water to avoid exchange with $\mathrm{CO}_{2}$ in air bubbles and water vapor and sealed with parafilm to avoid leakage. All samples were refrigerated and sent to the laboratory as soon as possible for further water quality analysis. $\mathrm{pH}$ values were determined by an acidity meter (PHS-3C) in the laboratory. Total dissolved solids (TDS) were analyzed by oven drying method. Major ions $\left(\mathrm{Mg}^{2+}, \mathrm{Na}^{+}, \mathrm{K}^{+}, \mathrm{Ca}^{2+}, \mathrm{SO}_{4}{ }^{2-}, \mathrm{NO}_{3}{ }^{-}\right.$, and $\left.\mathrm{Cl}^{-}\right)$were determined by ion chromatography (ISC-600). Total hardness (TH) was determined by titration with ethylene diamine tetracetic acid (EDTA) $(0.01 \mathrm{~mol} / \mathrm{L})$ and $\mathrm{HCO}_{3}{ }^{-}$was measured by titration using $0.05 \mathrm{M} \mathrm{HCl}$. In this study, the charge balance of most water samples was within $5 \%$. 


\subsection{Water Quality Assessment}

In this paper, the quality of groundwater for drinking uses was determined by using fuzzy comprehensive evaluation (FCE) [19]. The basic idea of the FCE is: (1) to establish the membership set of the comprehensive evaluation of groundwater quality (2) to determine the evaluation set, (3) to establish the membership function. The fuzzy membership function was computed for different water quality levels, using Equations (1)-(3) below.

The membership function of water quality of Level 1 , where $j=1$ :

$$
Y_{i j}= \begin{cases}1 & X_{i} \leq S_{i j} \\ X_{i}-S_{i(j+1)} & S_{i j}<X_{i}<S_{i(j+1)} \\ S_{i j}-S_{i(j+1)} & X_{i} \geq S_{i(j+1)}\end{cases}
$$

The membership function of water quality from Level 2 to $(\mathrm{m}-1)$, where $j=2,3, \cdots(\mathrm{m}-1)$ :

$$
Y_{i j}= \begin{cases}1 & X_{i} \leq S_{i(j-1)} \\ \frac{X_{i}-S_{i(j-1)}}{S_{i j}-S_{i(j-1)}} & S_{i(j-1)}<X_{i}<S_{i j} \\ \frac{X_{X}-S_{(j j+1)}}{S_{i j}-S_{i(j+1)}} & S_{i j}<X_{i}<S_{i(j+1)}\end{cases}
$$

The membership function of water quality of Level $\mathrm{m}$, where $j=\mathrm{m}$ :

$$
Y_{i j}= \begin{cases}1 & X_{i} \geq S_{i j} \\ \frac{X_{i}-S_{i(j-1)}}{S_{i j}-S_{i(j-1)}} & S_{i(j-1)}<X_{i}<S_{i j} \\ 0 & X_{i} \leq S_{i(j-1)}\end{cases}
$$

where $X_{i}$ is the actual monitoring value of the $i$ th evaluation factor and $S_{i j}$ is the standard limit value of $i$ th grade water quality of the $j$ th factor.

The membership degree of groundwater quality of each factor can form a fuzzy matrix $R$ :

$$
R=\left[\begin{array}{cccc}
Y_{11} & Y_{12} & \ldots & Y_{1 j} \\
Y_{21} & Y_{22} & \ldots & Y_{2 j} \\
\vdots & \vdots & \ldots & \vdots \\
Y_{i 1} & Y_{i 2} & \cdots & Y_{i j}
\end{array}\right]
$$

The normalized weight of each factor can be expressed as:

$$
W_{i}=\frac{\frac{C_{i}}{S_{i}}}{\sum_{i=1}^{n} \frac{C_{i}}{S_{i}}}
$$

where, $W_{i}$ indicates the normalized weight of parameter $i$, and $S_{i}$ is the mean of the standard value of each class.

Fuzzy comprehensive evaluation is based on matrix $D$, which can be expressed as:

$$
D=W \times R
$$

where, $W$ includes the weight of each factor.

Groundwater in the alluvial-diluvial plain of southwest Shandong Province is not only used for domestic and drinking applications, but also for agricultural irrigation. Therefore, the quality of 
groundwater for irrigation was also determined by calculating the sodium adsorption ratio (SAR) and percentage sodium (\% Na) (Table 2).

Table 2. Equations used for calculating sodium adsorption ratio (SAR) and \% Na.

\begin{tabular}{|c|c|c|c|c|}
\hline Equation & Equation & Range & Water class & Reference \\
\hline 1 & $\mathrm{SAR}=\frac{\mathrm{Na}^{+}}{\sqrt{\frac{\mathrm{Ca}^{2+}+\mathrm{Mg}^{2+}}{2}}}$ & $\begin{array}{c}<10 \\
10-18 \\
18-26 \\
>26\end{array}$ & $\begin{array}{c}\text { Excellent } \\
\text { Good } \\
\text { Doubtful } \\
\text { Unsuitable (S4) }\end{array}$ & [22] \\
\hline 2 & $\frac{\% \mathrm{Na}}{\mathrm{Ca}^{2+}+\mathrm{Mg}^{+}+\mathrm{K}^{+}+\mathrm{Na}^{+}+\mathrm{K}^{+}} \times 100$ & $\begin{array}{c}<20 \\
20-40 \\
40-60 \\
60-80 \\
>80\end{array}$ & $\begin{array}{c}\text { Excellent } \\
\text { Good } \\
\text { Permissible } \\
\text { Doubtful } \\
\text { Unsuitable }\end{array}$ & [23] \\
\hline
\end{tabular}

\section{Results and Discussion}

\subsection{Major Ion Chemistry}

Statistical analysis of the major ions $\left(\mathrm{Mg}^{2+}, \mathrm{Na}^{+}, \mathrm{K}^{+}, \mathrm{Ca}^{2+}, \mathrm{SO}_{4}{ }^{2-}, \mathrm{NO}_{3}{ }^{-}\right.$, and $\left.\mathrm{Cl}^{-}\right)$is the basis of understanding the hydrogeochemical characteristics of groundwater [24]. Statistical descriptions of the major ions found in groundwater are shown in Table 3. Overall, the mean concentrations of the major ions in groundwater samples from 2016 were higher than in 2017, except for $\mathrm{SO}_{4}{ }^{2-}$ and $\mathrm{K}^{+}$.

Table 3. Descriptive statistics of the major parameters of groundwater.

\begin{tabular}{|c|c|c|c|c|c|c|c|c|}
\hline \multirow{2}{*}{ Parameters } & \multicolumn{4}{|c|}{2016} & \multicolumn{4}{|c|}{2017} \\
\hline & Max & Min & Mean & SD & Max & Min & Mean & SD \\
\hline $\mathrm{pH}$ & 8.66 & 7.28 & 7.88 & 0.37 & 8.79 & 7.51 & 8.41 & 0.35 \\
\hline $\mathrm{TH}(\mathrm{mg} / \mathrm{L})$ & 1521.34 & 24.67 & 546.16 & 372.25 & 1329.54 & 63.59 & 503.77 & 294.31 \\
\hline TDS (mg/L) & 2687.00 & 536.00 & 1191.12 & 542.68 & 2812.00 & 552.00 & 1174.24 & 610.56 \\
\hline $\mathrm{Na}^{+}(\mathrm{mg} / \mathrm{L})$ & 641.80 & 88.65 & 287.06 & 142.33 & 738.19 & 77.71 & 244.58 & 159.20 \\
\hline $\mathrm{K}^{+}(\mathrm{mg} / \mathrm{L})$ & 6.55 & 0.35 & 1.53 & 1.18 & 30.09 & 0.21 & 3.26 & 7.10 \\
\hline $\mathrm{Ca}^{2+}(\mathrm{mg} / \mathrm{L})$ & 256.83 & 4.28 & 80.37 & 66.54 & 232.65 & 11.57 & 73.55 & 54.72 \\
\hline $\mathrm{Mg}^{2+}(\mathrm{mg} / \mathrm{L})$ & 245.78 & 2.60 & 83.92 & 57.79 & 181.83 & 5.61 & 77.83 & 45.85 \\
\hline $\mathrm{HCO}_{3}^{-}(\mathrm{mg} / \mathrm{L})$ & 831.40 & 302.33 & 595.17 & 134.31 & 837.68 & 295.33 & 513.13 & 128.39 \\
\hline $\mathrm{Cl}^{-}(\mathrm{mg} / \mathrm{L})$ & 794.86 & 42.97 & 269.58 & 239.63 & 668.50 & 13.86 & 194.79 & 174.32 \\
\hline $\mathrm{SO}_{4}{ }^{2-}(\mathrm{mg} / \mathrm{L})$ & 495.86 & 37.62 & 223.96 & 154.54 & 813.49 & 21.18 & 238.54 & 207.42 \\
\hline $\mathrm{NO}_{3}{ }^{-}(\mathrm{mg} / \mathrm{L})$ & 189.64 & 0 & 8.92 & 37.77 & 28.74 & 0 & 2.36 & 5.87 \\
\hline $\mathrm{T}\left({ }^{\circ} \mathrm{C}\right)$ & 20.1 & 15.4 & 13.1 & 3.54 & 19.3 & 12.6 & 15.2 & 3.16 \\
\hline SI (Anhydrite) & -1.13 & -3.44 & -2.09 & 0.65 & -1.14 & -2.85 & -2.02 & 0.49 \\
\hline SI (Aragonite) & 1.33 & -0.24 & 0.64 & 0.36 & 1.49 & 0.51 & 1.09 & 0.29 \\
\hline SI (Calcite) & 1.47 & -0.10 & 0.78 & 0.36 & 1.63 & 0.65 & 1.24 & 0.29 \\
\hline SI (Dolomite) & 3.08 & 0.11 & 1.86 & 0.77 & 3.53 & 1.66 & 2.66 & 0.58 \\
\hline SI (Gypsum) & -0.82 & -3.13 & -1.78 & 0.65 & -0.83 & -2.54 & -1.72 & 0.49 \\
\hline SI (Halite) & -4.96 & -6.61 & -5.96 & 0.48 & -5.07 & -7.00 & -6.17 & 0.50 \\
\hline
\end{tabular}

$\mathrm{Na}^{+}$is the dominant cation present in the collected water samples. The $\mathrm{Na}^{+}$concentration ranged from 88.65 to $641.80 \mathrm{mg} / \mathrm{L}$ in 2016 and from 77.71 to $738.19 \mathrm{mg} / \mathrm{L}$ and 2017, with a mean of 287.06 and $244.58 \mathrm{mg} / \mathrm{L}$, respectively. The dissolutions of halite and silicate can increase the concentration of $\mathrm{Na}^{+}$ in the samples. In addition, $\mathrm{Na}^{+}$may also come from cation exchange [25]. The average concentrations of $\mathrm{K}^{+}$were 4.53 and $3.26 \mathrm{mg} / \mathrm{L}$ in 2016 and 2017, respectively. The maximum $\mathrm{K}^{+}$concentration $(30.09 \mathrm{mg} / \mathrm{L})$ was observed in a sample from location HZ06 in 2017. The dissolution of carbonates is an important origin of $\mathrm{Ca}^{2+}$ and $\mathrm{Mg}^{2+}$ in the samples. The concentration of $\mathrm{Ca}^{2+}$ in 2016 was between 
$4.28 \mathrm{mg} / \mathrm{L}$ and $256.83 \mathrm{mg} / \mathrm{L}$ and between $11.57 \mathrm{mg} / \mathrm{L}$ and $232.56 \mathrm{mg} / \mathrm{L}$ for $2017 . \mathrm{Mg}^{2+}$ ranged from 2.60 to $245.78 \mathrm{mg} / \mathrm{L}$ in 2016 and from 5.61 to $181.83 \mathrm{mg} / \mathrm{L}$ in 2017. The mean concentrations of $\mathrm{Ca}^{2+}$ and $\mathrm{Mg}^{2+}$ are $80.37 \mathrm{mg} / \mathrm{L}, 83.92 \mathrm{mg} / \mathrm{L}, 73.55 \mathrm{mg} / \mathrm{L}$ and $77.83 \mathrm{mg} / \mathrm{L}$ in 2016 and 2017. The mean concentration of cations in the groundwater samples was $\mathrm{Na}^{+}>\mathrm{Mg}^{2+}>\mathrm{Ca}^{2+}>\mathrm{K}^{+}$for both 2016 and 2017.

$\mathrm{HCO}_{3}{ }^{-}$is the dominant anion in groundwater samples, with average concentrations in the order of $\mathrm{HCO}_{3}{ }^{-}>\mathrm{Cl}^{-}>\mathrm{SO}_{4}{ }^{2-}>\mathrm{NO}_{3}{ }^{-}$in 2016 and $\mathrm{HCO}_{3}{ }^{-}>\mathrm{SO}_{4}{ }^{2-}>\mathrm{Cl}^{-}>\mathrm{NO}_{3}{ }^{-}$in 2017. $\mathrm{HCO}_{3}{ }^{-}$ ranges from $302.33-831.40 \mathrm{mg} / \mathrm{L}$ in 2016 and $295.33-837.68 \mathrm{mg} / \mathrm{L}$ in 2017 , with a mean of 595.17 and $513.13 \mathrm{mg} / \mathrm{L}$, respectively. The average concentrations of $\mathrm{Cl}^{-}$and $\mathrm{SO}_{4}{ }^{2-}$ are 269.58 and 223.96 in 2016, and are 194.79 and $238.54 \mathrm{mg} / \mathrm{L}$ in 2017, respectively. Anthropogenic inputs, such as industrial and agricultural activities are a major source of $\mathrm{NO}_{3}{ }^{-}$in groundwater. The concentration of $\mathrm{NO}_{3}{ }^{-}$in the study area found to vary from 0 to $189.64 \mathrm{mg} / \mathrm{L}$ in 2016 and from 0 to $28.74 \mathrm{mg} / \mathrm{L}$ in 2017 . HZ10 had the highest $\mathrm{NO}_{3}{ }^{-}$concentration $(189.64 \mathrm{mg} / \mathrm{L})$ in 2016 , while every other sample had lower than $30 \mathrm{mg} / \mathrm{L}$.

As shown in Table 3, the $\mathrm{pH}$ values of groundwater samples ranged from 7.28 to 8.66 in 2016, with a mean of 7.88, while the $\mathrm{pH}$ values were between 7.51 and 8.79 in 2017, with an average of 8.41. TDS and TH are two important indices in assessing water quality $[7,9]$. The concentrations of TDS and TH vary from 536.00 to $2687.00 \mathrm{mg} / \mathrm{L}, 24.67$ to $1521.34 \mathrm{mg} / \mathrm{L}$ in 2016, and range from 552.00 to $2812.00 \mathrm{mg} / \mathrm{L}$ and 63.59 to $1329.54 \mathrm{mg} / \mathrm{L}$ in 2017, respectively. Most of water samples (Figure 2) were found belong to hard-fresh water (36\%) and hard-brackish water (50\%).

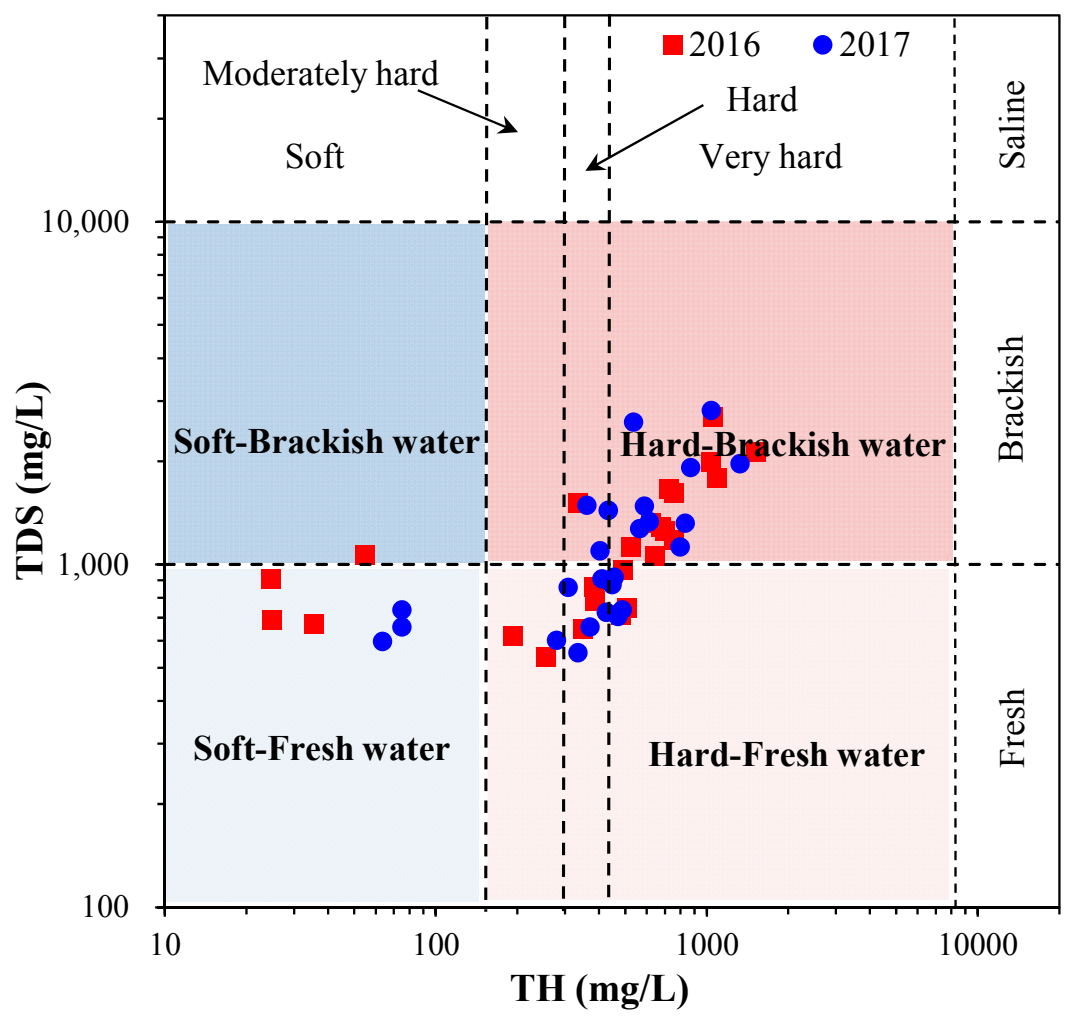

Figure 2. Plot of total dissolved solids (TDS) versus total hardness (TH) of groundwater.

\subsection{Water Types}

A Piper diagram is a simple and widely used method for determining the type of groundwater $[7,25]$. In this study, a Piper diagram was obtained by using the Aq.QA software. As shown in Figure 3, a Piper triangle consists of a diamond and two triangles, in which the diamond is divided into nine regions. The diamond shows the general hydrochemical characteristics of the water sample, while the triangle shows the relative content of each ion. Most of water samples belong to Zones 5, 7, and 9 in the diamond portion. For cations, most of water samples belong to Zones B 
and D (left lower triangle portion). With respect to anions, most water samples from 2016 and 2017 are in Zones B and E (right lower triangle portion). This indicates that the dominant water types are $\mathrm{HCO}_{3}-\mathrm{Na}$ and mixed types. The $\mathrm{HCO}_{3}-\mathrm{Na}$ water type is likely due to cation exchange and/or interaction with silicates [26,27]. In addition, 22\% and 16\% of the water samples from 2016 and 2017 are located in Zones 5 and 7, indicating that these samples are $\mathrm{HCO}_{3}-\mathrm{Ca}$ and $\mathrm{Cl}-\mathrm{Na}$ type water, respectively.

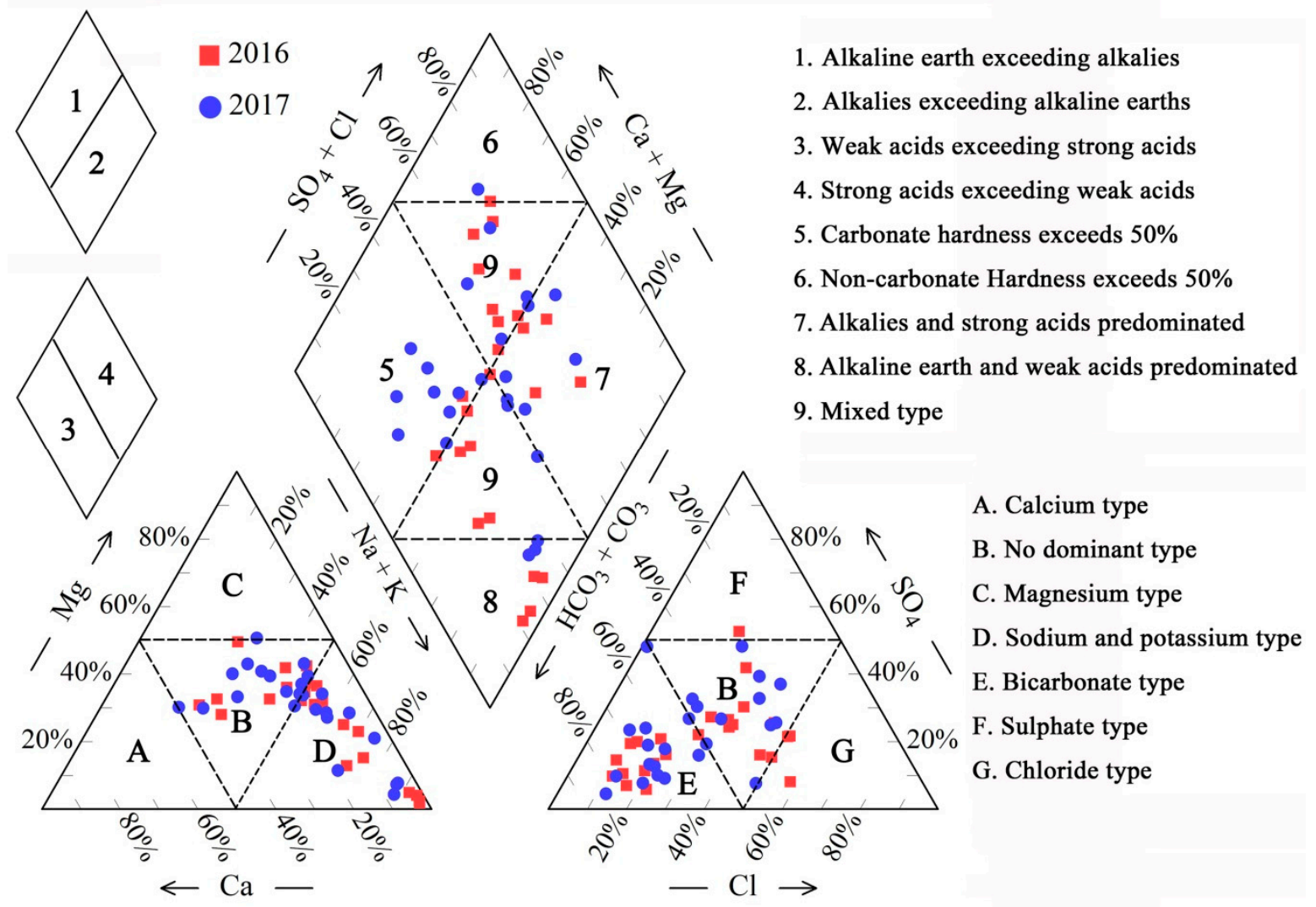

Figure 3. Piper diagram of 50 groundwater samples.

\subsection{Processes Influencing Groundwater Chemistry}

In general, precipitation, evaporation, and rock weathering are the three major natural mechanisms determining the water chemistry in the study area. Gibbs [28] built a simple and effective diagram comparing the concentration of TDS versus the weight ratios of $\mathrm{Na}^{+} /\left(\mathrm{Na}^{+}+\mathrm{Ca}^{2+}\right)$ or TDS versus the weight ratios of $\mathrm{Cl}^{-} /\left(\mathrm{Cl}^{-}+\mathrm{HCO}_{3}{ }^{-}\right)$to identify the influencing factors of the groundwater hydrochemistry. Figure 4 indicates that most of samples are located in the rock weathering dominant field, which indicates that water-rock interactions are the prevailing natural mechanism in determining the groundwater chemistry. In addition, it can be seen that the groundwater was also influenced by evaporation. The ratios of $\mathrm{Na}^{+} /\left(\mathrm{Na}^{+}+\mathrm{Ca}^{2+}\right)$ varied from 0.31 to 0.98 , with an average of 0.76 , suggesting a strong cation exchange in the groundwater system [7]. 

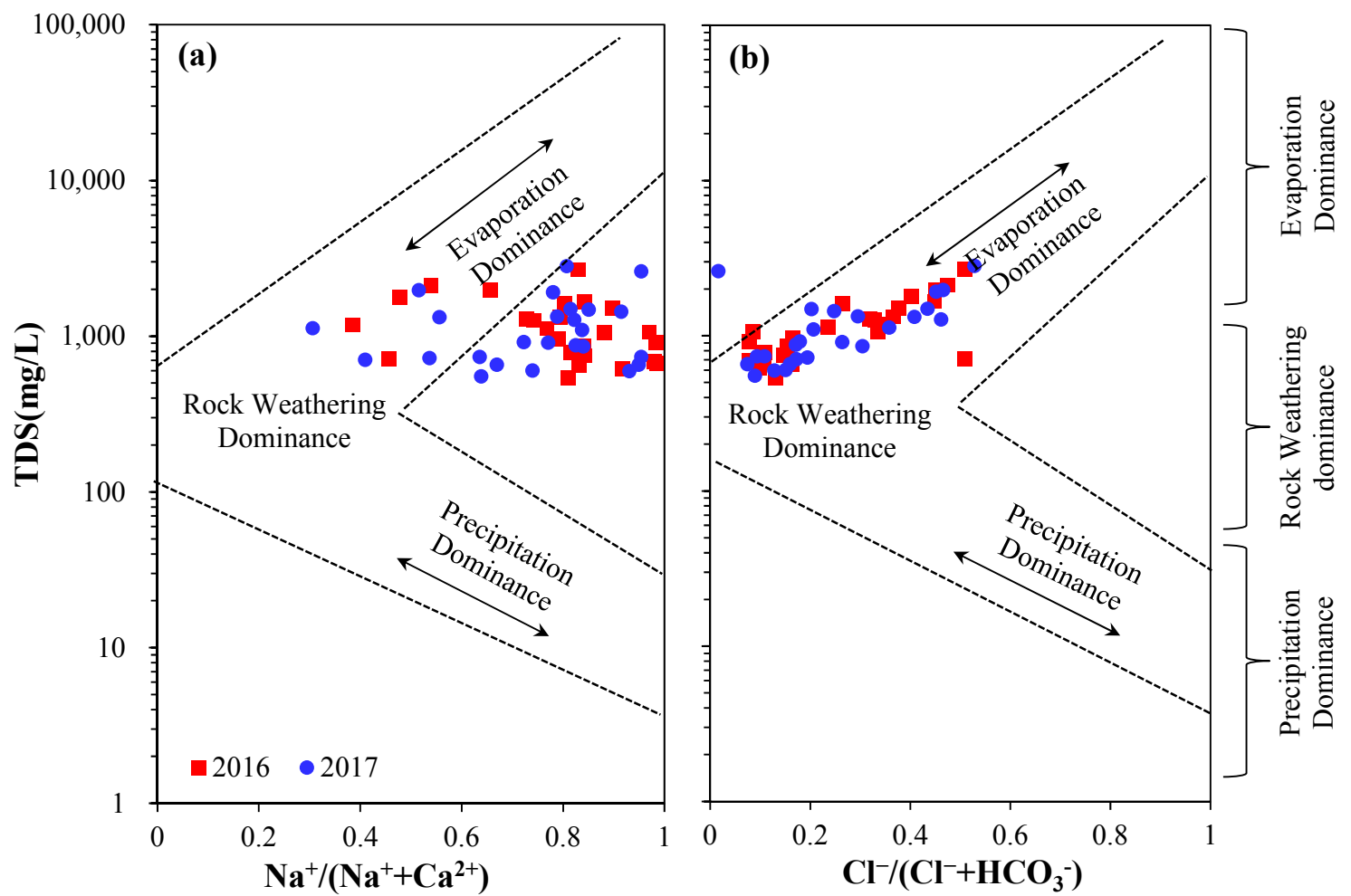

Figure 4. Gibbs diagram for groundwater samples.

Ion exchange, shown in Equations (7) and (8), is another important hydrogeochemical reaction affecting the composition of groundwater in the study region [15]. A diagram of $\left(\mathrm{Ca}^{2+}+\mathrm{Mg}^{2+}-\right.$ $\mathrm{HCO}_{3}{ }^{-}-\mathrm{SO}_{4}{ }^{2-}$ ) versus $\left(\mathrm{Na}^{+}+\mathrm{K}^{+}-\mathrm{Cl}^{-}\right.$) is a commonly used method to determine the occurrence of cation exchange processes [29]. Most of the water samples are close to the $y=-x$ line (Figure 5a) and only three deviated from this relationship, indicating that cation exchange plays a non-negligible role in controlling the hydrochemistry components of groundwater.
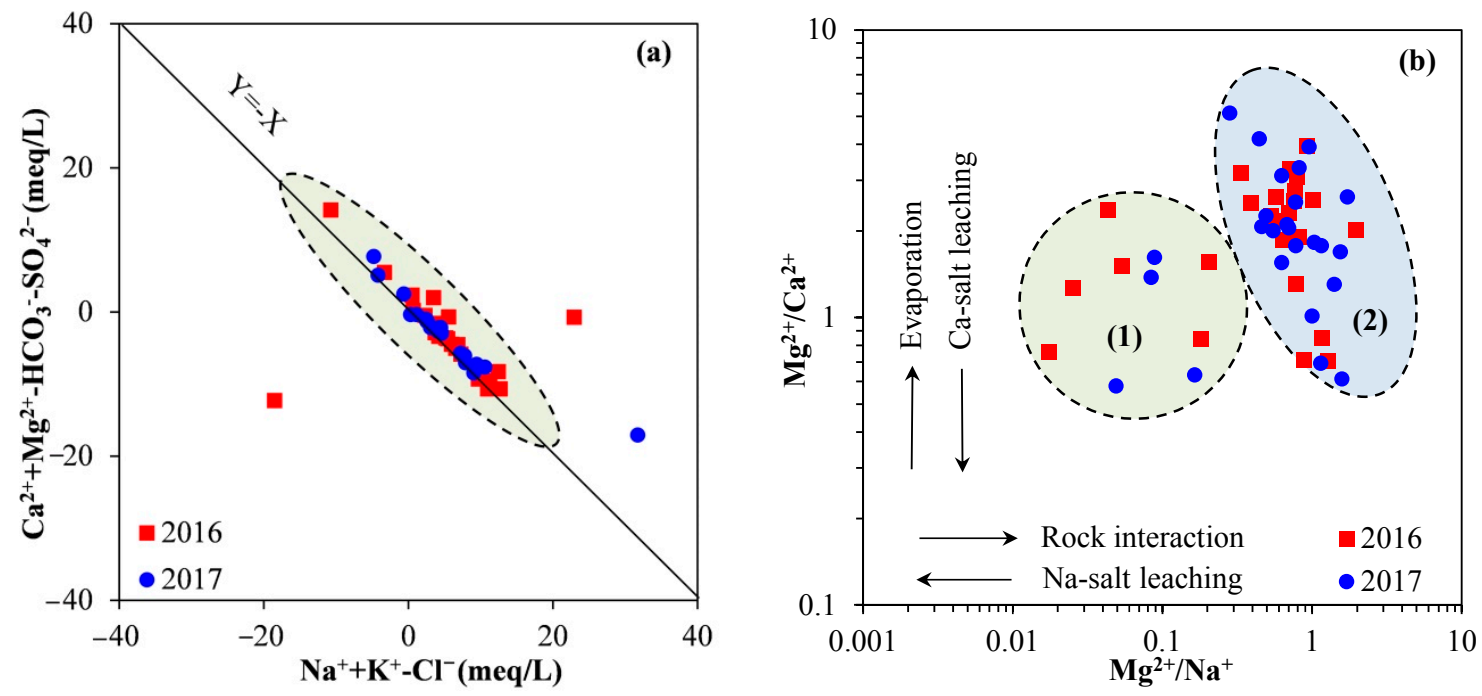

Figure 5. Plots showing (a) $\left(\mathrm{Ca}^{2+}+\mathrm{Mg}^{2+}-\mathrm{HCO}_{3}^{-}-\mathrm{SO}_{4}{ }^{2-}\right)$ versus $\left(\mathrm{Na}^{+}+\mathrm{K}^{+}-\mathrm{Cl}^{-}\right)$and (b) $\mathrm{Mg}^{2+} / \mathrm{Ca}^{2+}$ versus $\mathrm{Mg}^{2+} / \mathrm{Na}^{+}$.

The relationship of $\mathrm{Mg}^{2+} / \mathrm{Ca}^{2+}$ versus $\mathrm{Mg}^{2+} / \mathrm{Na}^{+}$can be used to analyze soil salt leaching and evaporation $[15,17]$. In the early stages of water evaporation, the concentration of $\mathrm{Mg}^{2+}$ does not 
increase due to soil salt leaching, nor does it decrease due to salt precipitation [15,17]. As shown in Figure 5b, groundwater samples were clearly divided into two zones. Zone 1 water samples had small $\mathrm{Mg}^{2+} / \mathrm{Na}^{+}$ratios and large $\mathrm{Mg}^{2+} / \mathrm{Ca}^{2+}$ ratios, indicating that evaporation was an important process controlling the water chemistry of these samples. Samples in Zone 2 had large ratios of both $\mathrm{Mg}^{2+} / \mathrm{Na}^{+}$ and $\mathrm{Mg}^{2+} / \mathrm{Ca}^{2+}$, suggesting that water-rock interactions and evaporation were the governing processes in the formation of the hydrochemical components in these samples.

$$
\begin{gathered}
\text { Ion exchange: } 2 \mathrm{NaX}+\mathrm{Ca}^{2+} \rightarrow 2 \mathrm{Na}^{+}+\mathrm{CaX}_{2} \\
\text { Reverse Ion exchange: } \mathrm{CaX}_{2}+2 \mathrm{Na}^{+} \rightarrow \mathrm{Ca}^{2+}+2 \mathrm{NaX}
\end{gathered}
$$

Chloro-alkaline indices (CAI) have been widely used to study cation exchange, and they can be expressed using Equations (9) and (10) [30]. When $\mathrm{Na}^{+}$and $\mathrm{K}^{+}$in the groundwater system exchange with $\mathrm{Mg}^{2+}$ or $\mathrm{Ca}^{2+}, \mathrm{CAI}$ values are positive. In this system, $\mathrm{Na}^{+}$and $\mathrm{K}^{+}$will decrease in groundwater, representing a direct ion exchange. When $\mathrm{CAI}$ indices are negative, it represents the reverse reaction. Most of the CAI values for the groundwater samples in CAI-1 and CAI-2 were both negative (Figure 6), while only one sample (HZ06) was positive. Therefore, $\mathrm{Ca}^{2+}$ and $\mathrm{Mg}^{2+}$ exchange with $\mathrm{Na}^{+}$and $\mathrm{K}^{+}$is the predominant cation exchange process. In addition, CAI values of samples HZ01, HZ07, HZ18, and H24 were opposite in 2016 and 2017, indicating that different cation exchanges took place at these points in 2016 and 2017.

$$
\begin{gathered}
\mathrm{CAI}-1=\frac{\mathrm{Cl}^{-}-\left(\mathrm{Na}^{+}+\mathrm{K}^{+}\right)}{\mathrm{Cl}^{-}} \\
\mathrm{CAI}-2=\frac{\mathrm{Cl}^{-}-\left(\mathrm{Na}^{+}+\mathrm{K}^{+}\right)}{\mathrm{SO}_{4}^{2-}+\mathrm{HCO}_{3}^{-}+\mathrm{CO}_{3}^{2-}+\mathrm{NO}_{3}^{-}}
\end{gathered}
$$
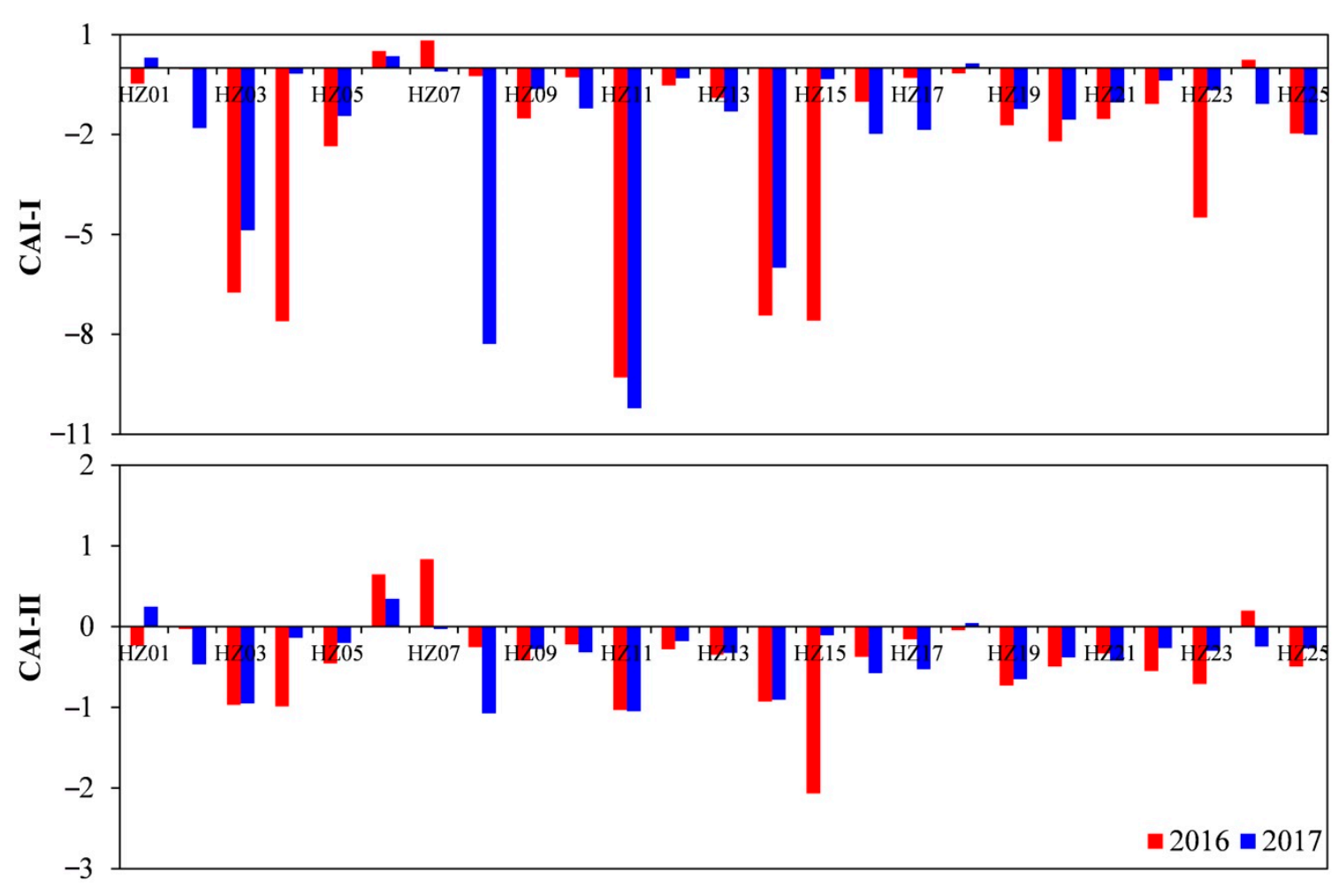

Figure 6. Bar diagram of chloro-alkaline indices for 2016 and 2017. 
Ratios of the major ions were used to further determine the sources and control the factors of the main hydrochemical components of the groundwater samples. In theory, the dissolution of halite should produce the same amount of $\mathrm{Na}^{+}$and $\mathrm{Cl}^{-}$(Equation (11)). Therefore, if halite dissolution controls the concentrations of $\mathrm{Na}^{+}$and $\mathrm{Cl}^{-}$in the groundwater system, the ratio of $\mathrm{Na}^{+} / \mathrm{Cl}^{-}$should be equal to 1 . However, most of the water samples are distributed below the $y=x$ line (Figure 7a), which indicates that the dissolution of halite is not the dominant origin of $\mathrm{Na}^{+}$in groundwater. $\mathrm{Na}^{+}$may also come from the weathering of silicates or cation exchange [12]. If the dissolution of gypsum is the major origin of $\mathrm{Ca}^{2+}$ and $\mathrm{SO}_{4}{ }^{2-}$, the equivalent ratio of $\mathrm{Ca}^{2+} / \mathrm{SO}_{4}{ }^{2-}$ should be equal to 1 (Equation (12)). However, Figure $7 \mathrm{~b}$ indicates that most water samples, when plotted, are on both sides of the $\mathrm{y}=\mathrm{x}$ line, suggesting that the dissolution of gypsum is not the major source of $\mathrm{Ca}^{2+}$ and $\mathrm{SO}_{4}{ }^{2-}$. The weathering of carbonate is a prevalent hydrogeochemical processes which produces $\mathrm{Ca}^{2+}, \mathrm{Mg}^{2+}$, and $\mathrm{HCO}_{3}{ }^{-}$ in groundwater [12]. If the dissolution of carbonates is the only source of $\mathrm{Ca}^{2+}, \mathrm{Mg}^{2+}$ and $\mathrm{HCO}_{3}{ }^{-}$, the ratios of $\mathrm{HCO}_{3}{ }^{-} / \mathrm{Ca}^{2+}$ and $\mathrm{HCO}_{3}{ }^{-} /\left(\mathrm{Ca}^{2+}+\mathrm{Mg}^{2+}\right)$ should be between 1 to 2 (Equations (13) and (14)). As shown in Figure $7 \mathrm{c}, \mathrm{d}$, some water samples are located between $\mathrm{y}=\mathrm{x}$ and $\mathrm{y}=\mathrm{x} / 2$, indicating that the dissolutions of calcite and dolomite are the major processes influencing water chemistry of these samples.

$$
\begin{aligned}
\mathrm{NaCl} & \rightarrow \mathrm{Na}^{+}+\mathrm{Cl}^{-} \\
\mathrm{CaSO}_{4} \cdot \mathrm{H}_{2} \mathrm{O} & \rightarrow \mathrm{Ca}^{2+}+\mathrm{SO}_{4}{ }^{2-}+2 \mathrm{H}_{2} \mathrm{O} \\
\mathrm{CaCO}_{3}+\mathrm{H}^{+} & \rightarrow \mathrm{Ca}^{2+}+\mathrm{HCO}_{3}{ }^{-} \\
\mathrm{CaMg}\left(\mathrm{CO}_{3}\right)_{2}+2 \mathrm{H}^{+} & \rightarrow \mathrm{Ca}^{2+}+\mathrm{Mg}^{2+}+2 \mathrm{HCO}_{3}{ }^{-}
\end{aligned}
$$

The dissolution of silicate, carbonate, and gypsum can provide $\mathrm{Ca}^{2+}, \mathrm{Mg}^{2+}, \mathrm{SO}_{4}{ }^{2-}$ and $\mathrm{HCO}_{3}{ }^{-}$in a groundwater system $[10,29]$. If the equivalent ratio of $\left(\mathrm{SO}_{4}{ }^{2-}+\mathrm{HCO}_{3}{ }^{-}\right) /\left(\mathrm{Ca}^{2+}+\mathrm{Mg}^{2+}\right)$ is equal to 1 , the dissolutions of carbonates (calcite and dolomite) and gypsum are the major hydrogeochemical reactions in groundwater system. In addition, the ratio of $\left(\mathrm{SO}_{4}{ }^{2-}+\mathrm{HCO}_{3}{ }^{-}\right) /\left(\mathrm{Ca}^{2+}+\mathrm{Mg}^{2+}\right)$ can be used to determine the ion exchange in a system [31]. If the samples are located below the $y=x$ line, cation exchange is a prevalent reaction in groundwater, while the samples above the $y=x$ line suggests the reverse cation exchange as a prevalent process (Equations (7) and (8)). Most of the water samples are located under the $\mathrm{y}=\mathrm{x}$ line (Figure $7 \mathrm{e}$ ), indicating that the ion exchange process causes a deficiency of $\mathrm{Ca}^{2+}$ ions, which is an important result of silicate weathering [31]. Most of the samples are located between the silicate and carbonate (Figure 7f), suggesting that the dissolutions of silicate and carbonates are the prevalent hydrogeochemical reactions in the groundwater system in the study area [32].

\subsection{Saturation Index (SI)}

Mineral equilibrium calculations can indicate the thermodynamic process. SI can help to identify the existence of some of the prevailing thermodynamic processes in a groundwater system [18]. In this studies, SI values of relevant minerals were calculated using the PHREEQC software. As shown in Table 1, the SI values for dolomite, calcite, and aragonite range from 0.11 to $3.08,-0.10$ to 1.47 , and -0.24 to 1.33 , with a mean of $1.86,0.78$, and 0.64 , respectively. These values indicate that most of samples are saturated with these minerals (Figure 8). The SI values for anhydrite, gypsum and halite vary from -344 to $-1.33,-3.13$ to -0.82 , and -6.61 to -4.96 , respectively, suggesting that the water samples are not saturated with anhydrite, gypsum and halite (Figure 8 ). This means that the samples have a tendency to dissolve these minerals continuously. 

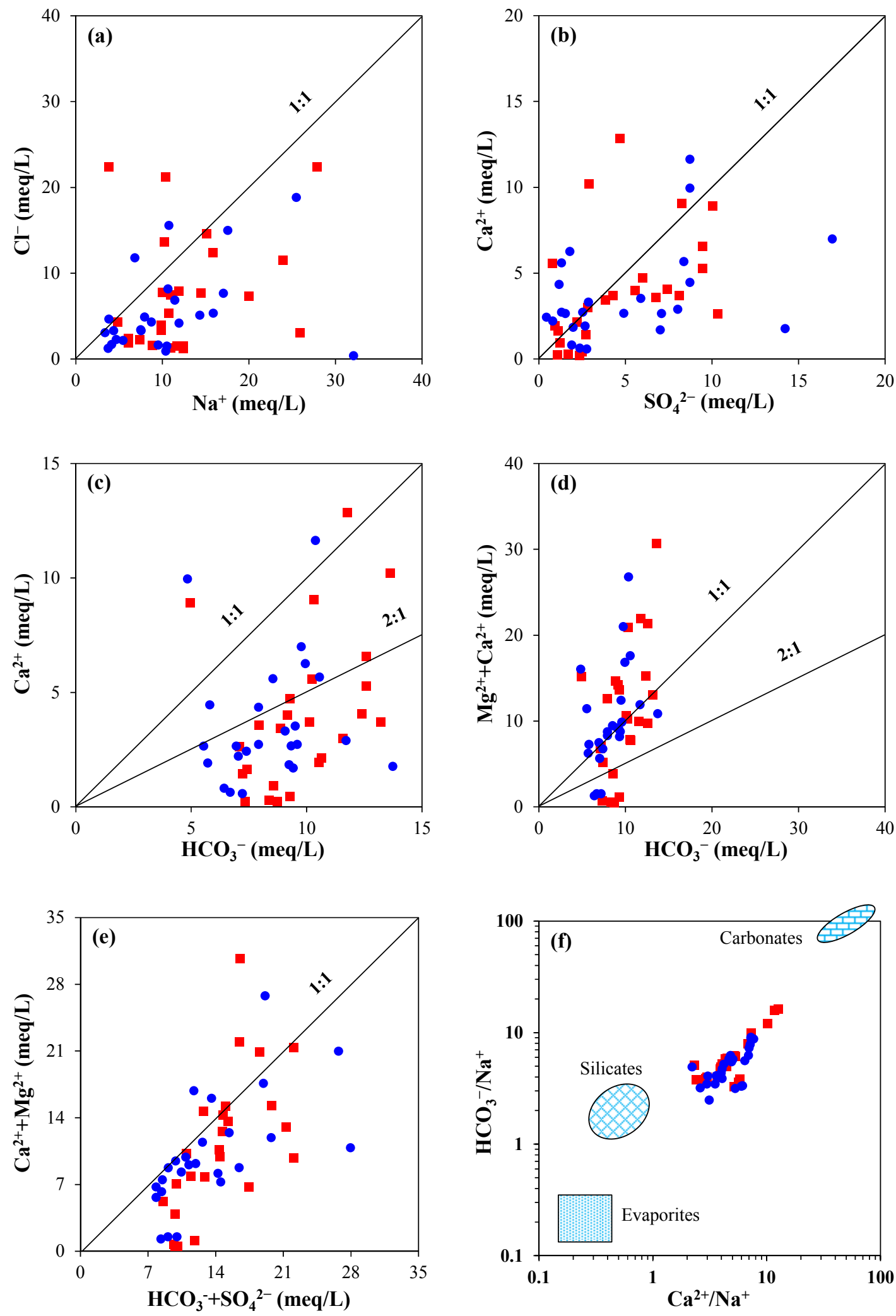

Figure 7. Plots showing (a) $\mathrm{Na}^{+}$versus $\mathrm{Cl}^{-}$, (b) $\mathrm{SO}_{4}{ }^{2-}$ versus $\mathrm{Ca}^{2+}$, (c) $\mathrm{HCO}_{3}{ }^{-}$versus $\mathrm{Ca}^{2+}$, (d) $\mathrm{HCO}_{3}{ }^{-}$ versus $\mathrm{Ca}^{2+}+\mathrm{Mg}^{2+}$, (e) $\left(\mathrm{SO}_{4}{ }^{2-}+\mathrm{HCO}_{3}{ }^{-}\right)$versus $\left(\mathrm{Ca}^{2+}+\mathrm{Mg}^{2+}\right)$, (f) $\left(\mathrm{HCO}_{3}{ }^{-} / \mathrm{Na}^{+}\right)$versus $\left(\mathrm{Ca}^{2+} / \mathrm{Na}^{+}\right)$. 


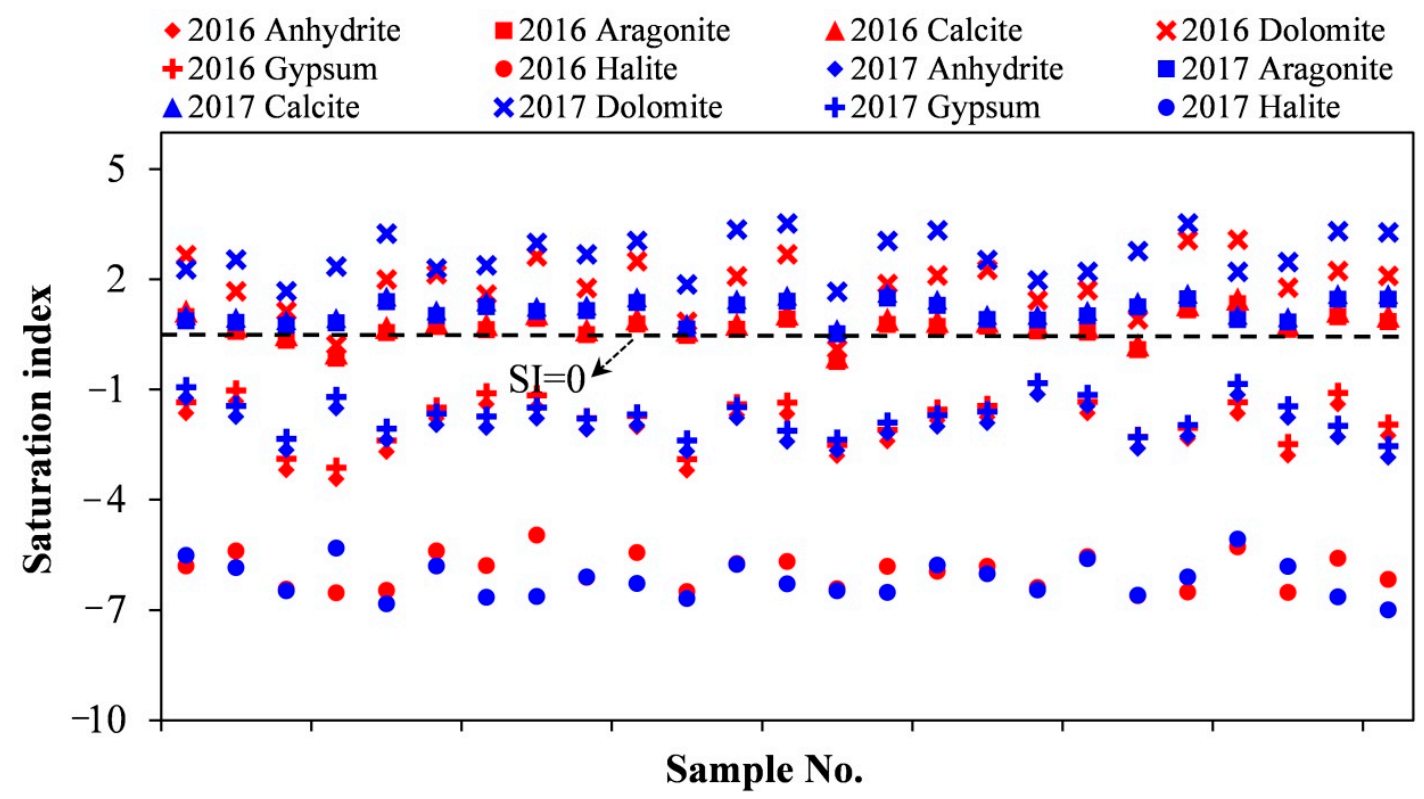

Figure 8. Saturation index (SI) for relevant minerals.

\subsection{Water Quality Assessment}

Water quality assessment of groundwater is a hot topic around the world, because the quality of water is directly related to human health. In this study, FCE was utilized to define the quality of groundwater for drinking uses. According to the Quality Standard for Groundwater of China [33], TDS, $\mathrm{TH}, \mathrm{Na}^{+}, \mathrm{Cl}^{-}, \mathrm{SO}_{4}{ }^{2-}, \mathrm{NO}_{3}{ }^{-}$and chemical oxygen demand (COD) were used to assess water quality (Table 4).

Table 4. Water quality standards of groundwater (Unit: mg/L; COD: chemical oxygen demand).

\begin{tabular}{ccccccccc}
\hline Class & TDS & TH & $\mathbf{N O}_{3}{ }^{-}$ & $\mathbf{S O}_{4}{ }^{2-}$ & $\mathbf{C l}^{-}$ & $\mathbf{N a}^{+}$ & COD & Suitability \\
\hline I & $300 \leq$ & $150 \leq$ & $8.86 \leq$ & $50 \leq$ & $50 \leq$ & $100 \leq$ & $1 \leq$ & Excellent \\
II & $500 \leq$ & $300 \leq$ & $22.14 \leq$ & $150 \leq$ & $150 \leq$ & $150 \leq$ & $2 \leq$ & Good \\
III & $1000 \leq$ & $450 \leq$ & $88.57 \leq$ & $250 \leq$ & $250 \leq$ & $200 \leq$ & $3 \leq$ & Medium \\
IV & $2000 \leq$ & $650 \leq$ & $132.86 \leq$ & $350 \leq$ & $350 \leq$ & $400 \leq$ & $10 \leq$ & Poor \\
V & $>2000$ & $>650$ & $>132.86$ & $>350$ & $>350$ & $>400$ & $>10$ & Very poor \\
\hline
\end{tabular}

Results of the quality of the groundwater for drinking purposes in 2016 and 2017 are shown in Table 5, Figures 9 and 10. The FCE results range from I to V, suggesting that the groundwater quality ranges from excellent to very poor. When the groundwater quality is found to be IV (poor) or $\mathrm{V}$ (very poor), the groundwater is unsuitable for drinking uses. For 2016, $48 \%$ of all samples were suitable for drinking use. The samples were found to be excellent $(4 \%)$, good $(8 \%)$, and medium $(36 \%)$ water. However, more than half of all samples were unsuitable for drinking, with all but one sample evaluated as very poor water and only HZ12 was categorized as poor water. Analysis of the samples from 2017 showed that $24 \%$ of the samples were classified as very poor water, and $16 \%$ of all samples are categorized as poor water. This means that more than half of the well water can be used as drinking water. The sixty percent of the samples which are of drinking quality are categorized as excellent $(8 \%)$, good $(16 \%)$, and medium $(36 \%)$ water. The percentage of groundwater samples which were classified as very poor in 2017 was less than in 2016. Overall, the groundwater quality in the samples taken in 2017 is better than the samples taken in 2016. This result may be influenced by the fact that groundwater sampling in 2016 took place in October and the test area had just experienced a flood season. Groundwater is recharged by atmospheric precipitation during the rainy season, and surface pollutants may enter the groundwater with the precipitation, which will affect the water 
quality. However, the sampling in 2017 was performed in June, and the test area had just gone through a dry season, with less precipitation and less surface pollutants entering groundwater. It is possible that this change in season is responsible for the difference in the groundwater quality between 2016 and 2017.

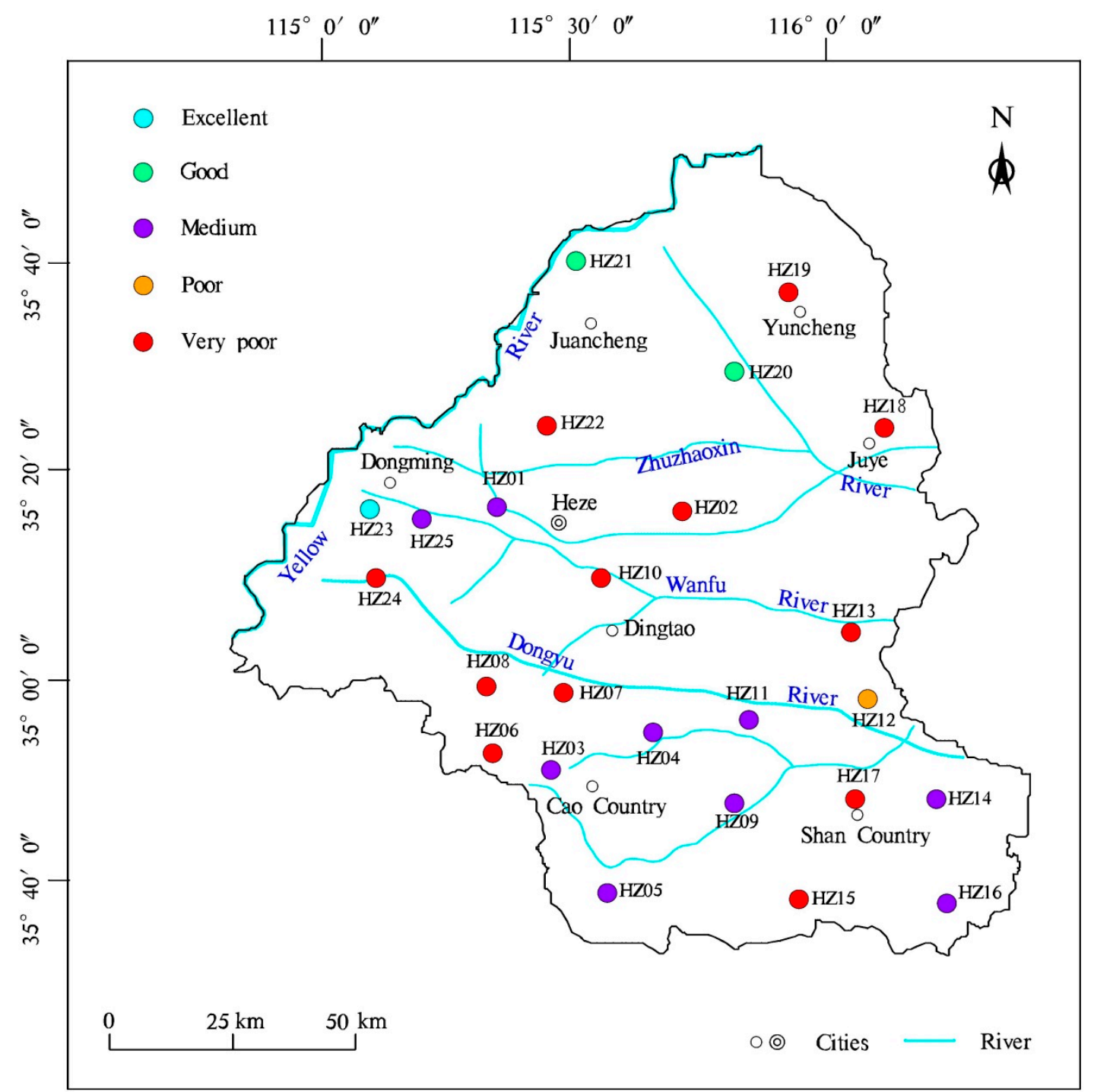

Figure 9. Results of groundwater quality for drinking uses in 2016.

The quality of groundwater appears to be a problem not just in the test area. For example, the quality of shallow groundwater and deep groundwater in Liaocheng City are mainly classified III and IV, respectively which means that the quality of groundwater is poor [34]. The sulfate concentration of groundwater in southern Zaozhuang area greatly exceeds the allowed amount. In addition to the influence of primary geological causes, the main reason for the increase of the sulfate concentration in the groundwater is the seepage of wastewater from industrial and mining enterprises [35]. Groundwater in Xuzhou area is not suitable for drinking, but it is suitable for domestic water and agricultural water uses [1].

Groundwater quality can also determine the suitability for irrigation, because high levels of ions in water can affect plant growth [18]. In order to determine the quality of the groundwater for agricultural irrigation purposes, SAR and \% Na were calculated and spatial maps of irrigation water quality were obtained by using universal kriging method. 


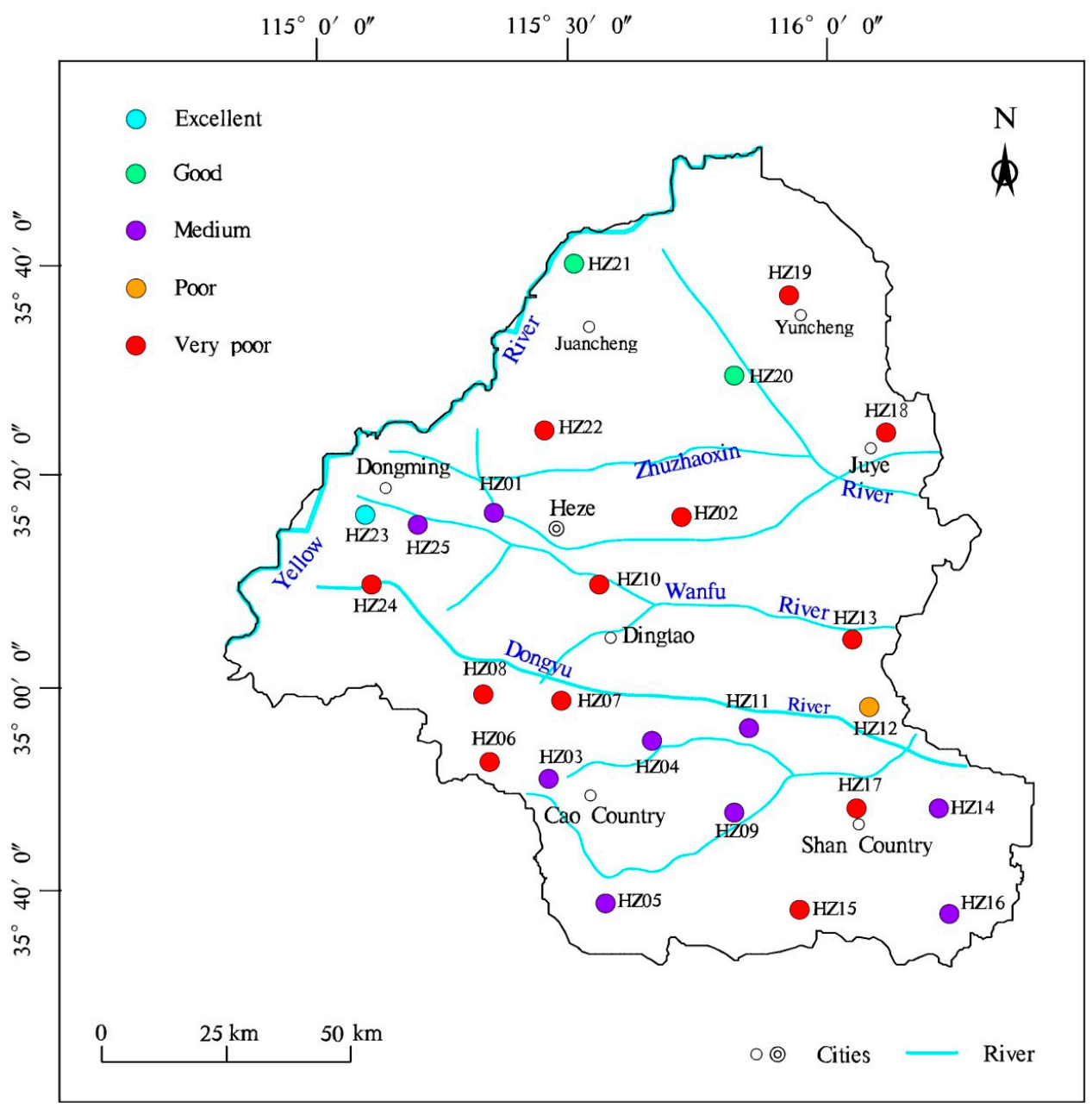

Figure 10. Results of groundwater quality for drinking uses in 2017.

SAR values for the 25 groundwater samples in 2016 ranged from 1.75 to 24.81 , with a mean of 7.69. Seventy six percent of these groundwater samples were found to be excellent water for irrigation, $12 \%$ of the samples belonged to good water, and three samples (12\%) categorized as doubtful water (Figure 11a). The groundwater samples from 2017 had $84 \%$ of samples classified as excellent water and $16 \%$ of the samples belonging to good water. The spatial maps based on SAR indicated that only a small region of the study area was presented as a doubtful irrigation water zone (Figure 11b). Overall, the groundwater quality is suitable for agricultural irrigation.

Irrigation water can be divided into five categories according to \% Na. As shown in Table 5, \% Na values of groundwater samples for 2016 and 2017 range from 24.87 to 96.13 and 19.99 to 88.21, and the mean values of \% $\mathrm{Na}$ are 56.38 and 51.17, respectively. Most of the groundwater samples from 2016 and 2017 are good or permissible water, while 16\% of all groundwater samples from 2016 belong to doubtful water and $12 \%$ of all samples from 2017 are classified as doubtful water. Four groundwater samples (HZ03, HZ04, HZ11, and HZ14) from 2016 were categorized as unsuitable water for agriculture irrigation uses, and three samples (HZ03, HZ11 and HZ14) from 2017 were also categorized as unsuitable water (Figure 11c,d).

The quality of groundwater is related to the safety of drinking water and the economic development of society. Under the accelerating process of urbanization and industrialization, dynamic monitoring of groundwater quality should be strengthened, pollution sources should be controlled, resources should be exploited reasonably, and resources should be utilized and protected to boost regional economic development. 
Table 5. Assessment results of the Fuzzy comprehensive evaluation (FCE), sodium adsorption ratio (SAR) and \% Na value in 2016 and 2017.

\begin{tabular}{|c|c|c|c|c|c|c|c|c|c|c|c|c|}
\hline & & & & & 2016 & & & & & 2017 & & \\
\hline & FCE & Water Quality & SAR & Water Quality & $\mathrm{Na} \%$ & Water Quality & FCE & Water Quality & SAR & Water Quality & $\mathrm{Na} \%$ & Water Quality \\
\hline HZ01 & III & Medium & 4.20 & Excellent & 44.62 & Permissible & V & Very Poor & 2.94 & Excellent & 28.70 & Good \\
\hline $\mathrm{HZO2}$ & $\mathrm{V}$ & Poor & 4.67 & Excellent & 42.02 & Permissible & IV & Poor & 5.87 & Excellent & 54.66 & Permissible \\
\hline HZ03 & III & Medium & 19.49 & Doubtful & 94.22 & Unsuitable & III & Medium & 11.92 & Good & 88.21 & Unsuitable \\
\hline HZ04 & III & Medium & 21.98 & Doubtful & 95.67 & Unsuitable & V & Very Poor & 5.92 & Excellent & 49.95 & Permissible \\
\hline HZ05 & III & Medium & 3.74 & Excellent & 48.67 & Permissible & I & Excellent & 1.86 & Excellent & 29.67 & Good \\
\hline HZ06 & $\mathrm{V}$ & Very Poor & 2.65 & Excellent & 25.39 & Good & $\mathrm{V}$ & Very Poor & 2.35 & Excellent & 31.12 & Good \\
\hline HZ07 & $\mathrm{V}$ & Very Poor & 1.75 & Excellent & 28.53 & Good & III & Medium & 1.55 & Excellent & 26.34 & Good \\
\hline HZ08 & $\mathrm{V}$ & Very Poor & 8.54 & Excellent & 56.71 & Permissible & $\mathrm{V}$ & Very Poor & 13.78 & Good & 74.76 & Doubtful \\
\hline HZ09 & III & Medium & 4.44 & Excellent & 49.93 & Permissible & III & Medium & 3.91 & Excellent & 48.95 & Permissible \\
\hline HZ10 & $\mathrm{V}$ & Very Poor & 5.86 & Excellent & 52.02 & Permissible & III & Medium & 3.51 & Excellent & 45.10 & Permissible \\
\hline HZ11 & III & Medium & 24.81 & Doubtful & 96.13 & Unsuitable & III & Medium & 11.95 & Good & 87.32 & Unsuitable \\
\hline HZ12 & IV & Poor & 4.77 & Excellent & 48.79 & Permissible & IV & Poor & 4.46 & Excellent & 48.31 & Permissible \\
\hline HZ13 & $\mathrm{V}$ & Very Poor & 5.24 & Excellent & 48.78 & Permissible & III & Medium & 3.55 & Excellent & 45.55 & Permissible \\
\hline HZ14 & III & Medium & 16.73 & Good & 91.85 & Unsuitable & III & Medium & 12.11 & Good & 87.47 & Unsuitable \\
\hline HZ15 & $\mathrm{V}$ & Very Poor & 11.46 & Good & 71.70 & Doubtful & III & Medium & 2.09 & Excellent & 33.44 & Good \\
\hline HZ16 & III & Medium & 4.67 & Excellent & 50.35 & Permissible & IV & Poor & 7.59 & Excellent & 64.47 & Doubtful \\
\hline HZ17 & III & Medium & 3.76 & Excellent & 41.40 & Permissible & III & Medium & 5.90 & Excellent & 59.44 & Permissible \\
\hline HZ18 & V & Very Poor & 1.76 & Excellent & 24.87 & Excellent & V & Very Poor & 1.35 & Excellent & 19.99 & Excellent \\
\hline HZ19 & V & Very Poor & 10.89 & Good & 74.82 & Doubtful & IV & Poor & 8.95 & Excellent & 70.19 & Doubtful \\
\hline HZ2O & II & Good & 3.79 & Excellent & 54.27 & Permissible & II & Good & 3.25 & Excellent & 49.38 & Permissible \\
\hline HZ21 & II & Good & 3.26 & Excellent & 46.51 & Permissible & II & Good & 4.96 & Excellent & 58.48 & Permissible \\
\hline HZ22 & V & Very Poor & 9.37 & Excellent & 64.79 & Doubtful & V & Very poor & 7.87 & Excellent & 55.38 & Permissible \\
\hline HZ23 & I & Excellent & 6.35 & Excellent & 69.55 & Doubtful & III & Good & 4.59 & Excellent & 47.99 & Permissible \\
\hline HZ24 & V & Very Poor & 3.09 & Excellent & 31.98 & Good & II & Good & 2.41 & Excellent & 38.65 & Good \\
\hline HZ25 & III & Medium & 5.00 & Excellent & 56.02 & Permissible & II & Good & 2.03 & Excellent & 35.72 & Good \\
\hline
\end{tabular}



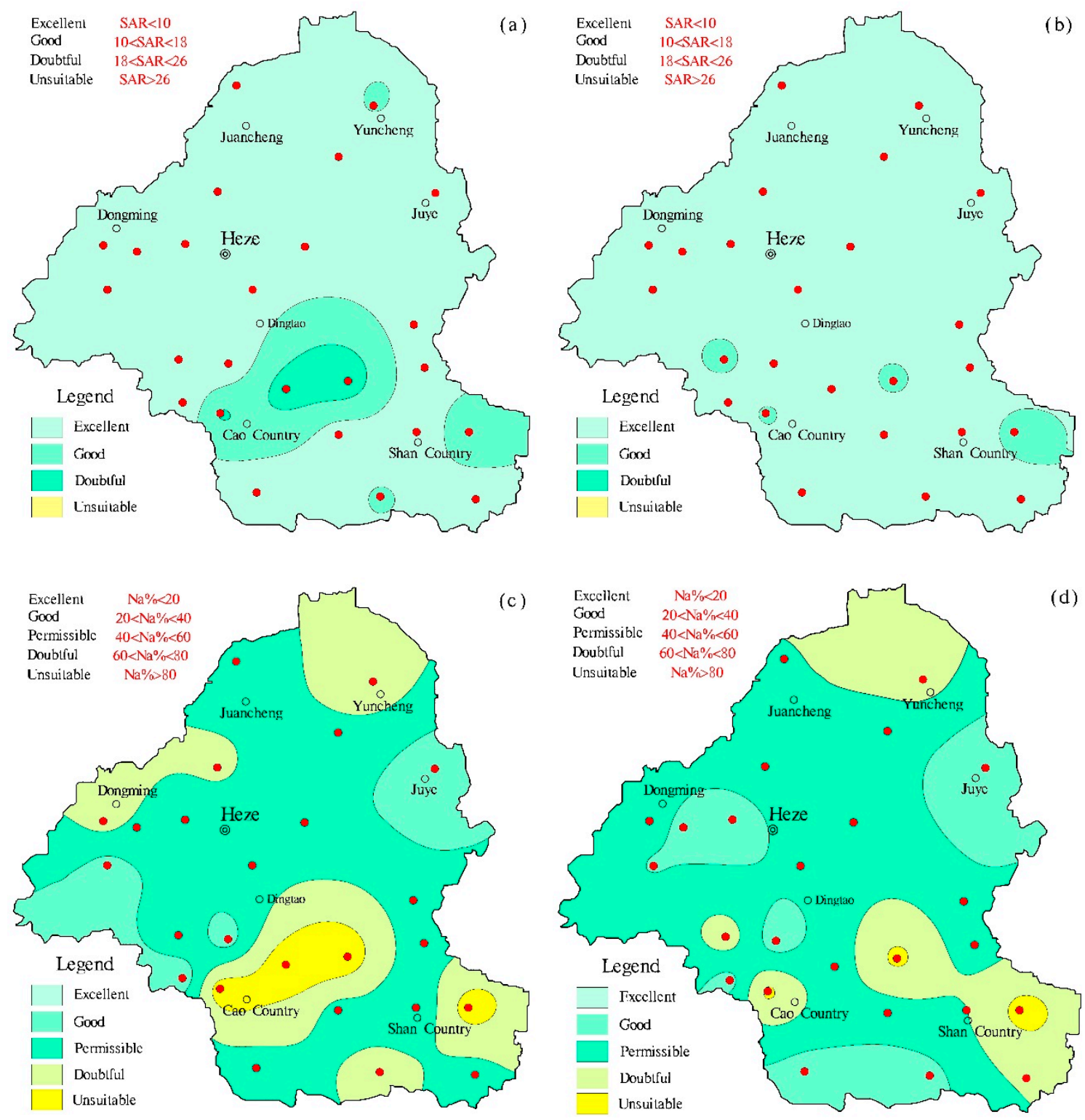

Figure 11. Distributed map of SAR and \% Na: (a) SAR in 2016, (b) SAR in 2017, (c) \% Na in 2016 and (d) \% Na in2017.

\section{Conclusions}

In this paper, the hydrogeochemical characteristics of groundwater for the alluvial-diluvial plain of southwest Shandong Province, and the groundwater's quality for drinking and irrigation uses were determined. The concentrations of the major cations in the groundwater are $\mathrm{Na}^{+}>\mathrm{Mg}^{2+}>$ $\mathrm{Ca}^{2+}>\mathrm{K}^{+}$, while with respect to anions, the order is $\mathrm{HCO}_{3}{ }^{-}>\mathrm{Cl}^{-}>\mathrm{SO}_{4}{ }^{2-}>\mathrm{NO}_{3}{ }^{-}$in 2016 and $\mathrm{HCO}_{3}{ }^{-}>\mathrm{SO}_{4}{ }^{2-}>\mathrm{Cl}^{-}>\mathrm{NO}_{3}{ }^{-}$in 2017. Mean concentrations of the major ions in groundwater samples from 2016 are higher than in samples from 2017, except $\mathrm{SO}_{4}{ }^{2-}$ and $\mathrm{K}^{+}$. Most of the water samples belong to hard-fresh water and hard-brackish water and the dominant water types are $\mathrm{HCO}_{3}-\mathrm{Na}$ and mixed types. Rock weathering and evaporation are the predominant processes in the formation of hydrochemical components. Dissolutions of silicate, calcite, dolomite, and gypsum are the dominant processes contributing to and defining the groundwater chemistry. In addition, cation exchange $\left(\mathrm{Ca}^{2+}\right.$ and $\mathrm{Mg}^{2+}$ exchange with $\mathrm{Na}^{+}$and $\mathrm{K}^{+}$) is also a non-negligible hydrogeochemical process. Based on FCE, the groundwater quality ranged from excellent to very poor. More than $50 \%$ of all groundwater 
samples from 2016 are categorized as poor or very poor water, indicating that these waters are unsuitable for drinking. According to SAR and $\% \mathrm{Na}$, most of samples are suitable for the purpose of irrigation. Overall, the groundwater quality of the samples from 2017 is better than the samples taken in 2016. Under the accelerating process of urbanization and industrialization, it is necessary to strengthen the dynamic monitoring of groundwater quality and control groundwater pollution sources so as to realize the rational development, utilization and protection of groundwater resources.

Author Contributions: Conceptualization, Z.G. and J.F.; Methodology, Z.G., J.L. and J.F.; Formal Analysis, Z.G., J.L., J.L. and M.W.; Writing-Original Draft Preparation, Z.G., J.L., J.F. and M.W.; Writing-Review \& Editing, Z.G., J.L. and J.F.; Resources, Z.G. and G.W.; Project Administration, Z.G. and G.W.; All authors read and approved the final manuscript.

Funding: This research received no external funding.

Acknowledgments: This research was supported by the Shandong Geological Environmental Monitoring Station. The authors sincerely thank the researchers and staff members for their help and thank editors and reviewers for reviewing the manuscript.

Conflicts of Interest: The authors declare no conflict of interest.

\section{References}

1. Yang, J.; Yu, Z.B.; Yi, P.; Aldahan, A. Assessment of groundwater quality and 222Rn distribution in the Xuzhou region, China. Environ. Monit. Assess. 2018, 190, 549. [CrossRef] [PubMed]

2. Liu, J.T.; Gao, Z.J.; Wang, M.; Li, Y.Z.; Ma, Y.Y.; Shi, M.J.; Zhang, H.Y. Study on the dynamic characteristics of groundwater in the valley plain of Lhasa City. Environ. Earth Sci. 2018, 77, 646. [CrossRef]

3. Qin, R.; Wu, Y.; Xu, Z.; Xie, D.; Zhang, C. Assessing the impact of natural and anthropogenic activities on groundwater quality in coastal alluvial aquifers of the lower Liaohe River Plain, NE China. Appl. Geochem. 2013, 31, 142-158. [CrossRef]

4. Foster, S.; Chilton, J.; Nijsten, G.J.; Richts, A. Groundwater-A global focus on the 'local resource'. Curr. Opin. Environ. Sustain. 2013, 5, 685-695. [CrossRef]

5. An, Y.K.; Lu, W.X. Assessment of groundwater quality and groundwater vulnerability in the northern Ordos Cretaceous Basin, China. Arab. J. Geosci. 2018, 11, 118. [CrossRef]

6. Kumar, P.J.S.; James, E.J. Geostatistical and geochemical model-assisted hydrogeochemical pattern recognition along the groundwater flow paths in Coimbatore district, South India. Environ. Dev. Sustain. 2019, 21, 369-384. [CrossRef]

7. $\mathrm{Wu}, \mathrm{C} . ; \mathrm{Wu}, \mathrm{X}$; Qian, C.; Zhu, G. Hydrogeochemistry and groundwater quality assessment of high fluoride levels in the Yanchi endorheic region, northwest China. Appl. Geochem. 2018, 98, 404-417. [CrossRef]

8. Abboud, I.A. Geochemistry and quality of groundwater of the Yarmouk basin aquifer, north Jordan. Environ. Geochem. Health 2018, 40, 1405-1435. [CrossRef]

9. Li, P.Y.; Wu, J.H.; Qian, H. Hydrogeochemistry and Quality Assessment of Shallow Groundwater in the Southern Part of the Yellow River Alluvial Plain (Zhongwei Section), Northwest China. Earth Sci. Res. J. 2014, 18, 27-38. [CrossRef]

10. Yang, Q.C.; Li, Z.J.; Ma, H.Y.; Wang, L.C.; Martín, J.D. Identification of the hydrogeochemical processes and assessment of groundwater quality using classic integrated geochemical methods in the Southeastern part of Ordos basin, China. Environ. Pollut. 2016, 218, 879-888. [CrossRef]

11. Zaki, S.R.; Redwan, M.; Masoud, A.M.; Moneim, A.A.A. Chemical characteristics and assessment of groundwater quality in Halayieb area, southeastern part of the Eastern Desert, Egypt. Geosci. J. 2018, 23, 149-164. [CrossRef]

12. Li, P.Y.; Wu, J.H.; Qian, H. Hydrochemical appraisal of groundwater quality for drinking and irrigation purposes and the major influencing factors: A case study in and around Hua County, China. Arab. J. Geosci. 2016, 9, 1-17. [CrossRef]

13. Jain, C.K.; Vaid, U. Assessment of groundwater quality for drinking and irrigation purposes using hydrochemical studies in Nalbari district of Assam, India. Environ. Earth Sci. 2018, 77, 254. [CrossRef] 
14. Tiwari, A.K.; Ghione, R.; Maio, M.D.; Lavy, M. Evaluation of hydrogeochemical processes and groundwater quality for suitability of drinking and irrigation purposes: A case study in the Aosta Valley region, Italy. Arab. J. Geosci. 2017, 10, 264. [CrossRef]

15. Zhang, T.; Cai, W.T.; Li, Y.Z.; Geng, T.T.; Zhang, Z.Y.; Lv, Y.G.; Zhao, M.; Liu, J.W. Ion chemistry of groundwater and the possible controls within Lhasa River Basin, SW Tibetan Plateau. Arab. J. Geosc. 2018, 11, 510. [CrossRef]

16. Liu, J.T.; Gao, Z.J.; Wang, M.; Li, Y.Z.; Ma, Y.Y.; Shi, M.J.; Zhang, H.; Ma, Y. Hydrochemical characteristics and possible controls in the groundwater of the Yarlung Zangbo River Valley, China. Environ. Earth Sci. 2019, $78,76$. [CrossRef]

17. Xiao, J.; Jin, Z.D.; Wang, J.; Zhang, F. Hydrochemical characteristics, controlling factors and solute sources of groundwater within the Tarim River Basin in the extreme arid region, NW Tibetan Plateau. Quatern. Int. 2015, 380, 237-246. [CrossRef]

18. Nematollahi, M.J.; Ebrahimi, P.; Razmara, M.; Ghasemi, A. Hydrogeochemical investigations and groundwater quality assessment of Torbat-Zaveh plain, Khorasan Razavi, Iran. Environ. Monit. Assess. 2016, 188, 2. [CrossRef]

19. Zhang, B.; Song, X.; Zhang, Y.; Han, D.; Tang, C.; Yu, Y.; Ma, Y. Hydrochemical characteristics and water quality assessment of surface water and groundwater in Songnen plain, Northeast China. Water Res. 2012, 46, 2737-2748. [CrossRef]

20. Zhang, Q.; Wang, S.; Yousaf, M.; Wang, S.; Nan, Z.; Ma, J.; Wang, D.; Zang, F. Hydrochemical characteristics and water quality assessment of surface water in the northeast Tibetan plateau of China. Water Sci. Technol. Water Supply 2017, 5, 1757-1768. [CrossRef]

21. Xu, J.Y.; Mao, L.; Zhang, T.; Wang, Z.S. The development and utilization of water resources and security assurance planning study in Heze City. China Popul. Resour. Environ. 2017, 27, 200-203.

22. Richards, L. Diagnosis and improvement of saline and alkali soils. In United States Salinity Laboratory; (vol.60, Agriculture Handbook); US Department of Agriculture: Washington, DC, USA, 1954; p. 160.

23. Wilcox, L.V. The quality of water for irrigation use. US Dep. Agric. Technol. Bull. 1948, 40, 962.

24. Zhou, P.P.; Wang, Z.M.; Zhang, J.Y.; Yang, Z.X.; Li, X.L. Study on the hydrochemical characteristics of groundwater along the Taklimakan Desert Highway. Environ. Earth Sci. 2016, 75, 1378. [CrossRef]

25. Li, P.Y.; Zhang, Y.T.; Yang, N.; Jing, L.J.; Yu, P.Y. Major Ion Chemistry and Quality Assessment of Groundwater in and Around a Mountainous Tourist Town of China. Expos. Health 2016, 8, 239-252. [CrossRef]

26. Venturelli, G.; Boschetti, T.; Duchi, V. Na-carbonate waters of extreme composition: Possible origin and evolution. Geochem. J. 2003, 37, 351-366. [CrossRef]

27. Toran, L.E.; Saunders, J.A. Modeling alternative paths of chemical evolution of $\mathrm{Na}_{-} \mathrm{HCO}_{3}$-type groundwater near Oak Ridge, Tennessee, USA. Hydrogeol. J. 1999, 7, 355-364. [CrossRef]

28. Gibbs, R.J. Mechanisms controlling world water chemistry. Science 1970, 170, 870. [CrossRef]

29. Xiao, J.; Jin, Z.D.; Zhang, F.; Wang, J. Solute geochemistry and its sources of the groundwaters in the Qinghai Lake catchment, NW China. J. Asian. Earth Sci. 2012, 52, 21-30. [CrossRef]

30. Schoeller, H. Qualitative evaluation of groundwater resources. In Methods and Techniques of Groundwater Investigation and Development; Water Research Series; UNESCO: Paris, France, 1965; pp. 54-83.

31. Zhang, Y.; Xu, M.; Li, X.; Qi, J.; Zhang, Q.; Guo, J.; Yu, L.; Zhao, R. Hydrochemical characteristics and multivariate statistical analysis of natural water system: A case study in Kangding County, Southwestern China. Water 2018, 10, 80. [CrossRef]

32. Gaillardet, J.; Dupré, B.; Louvat, P.; Allegre, C.J. Global silicate weathering and $\mathrm{CO}_{2}$ consumption rates deduced from the chemistry of large rivers. Cheml. Geol. 1999, 159, 3-30. [CrossRef]

33. Ministry of Natural Resources of the People's Republic of China. Standard for Groundwater Quality of China; Ministry of Natural Resources of the People's Republic of China: Beijing, China, 2017.

34. Li, Y.; Ji, L.J.; Dou, B.C.; Li, F.R.; Sun, J.F. Research on characteristics of groundwater quality and slection of assessment method in Liaocheng. J. Water Resour. Water Eng. 2015, 26, 29-34.

35. Ma, Y.H.; Su, C.L.; Liu, W.J.; Zhu, Y.P.; Li, J.X. Identification of sulfate sources in the groundwater system of Zaozhuang: Evidences from isotopic and hydrochemical characteristics. Environ. Sci. 2016, 37, 4690-4699.

(C) 2019 by the authors. Licensee MDPI, Basel, Switzerland. This article is an open access article distributed under the terms and conditions of the Creative Commons Attribution (CC BY) license (http://creativecommons.org/licenses/by/4.0/). 